\title{
Pengembangan sistem otomatisasi pembangkitan kasus uji dengan algoritma genetika dan test case generation method
}

\section{Development of automation systems for generating test cases with genetic algorithms and test case generation methods}

\author{
Moh Arsyad Mubarak Setyawan a, Fajar Pradana b, Bayu Priyambadha c \\ $a, b, c$ Teknik Informatika, Universitas Brawijaya, Malang, Indonesia \\ email: ${ }^{a}$ arzad.mubarak@gmail.com, ${ }^{b}$ fajar.p@ub.ac.id, cbayu_priyambadha@ub.ac.id
}

\begin{tabular}{l}
\hline I N F O A R T I K E L \\
\hline Sejarah artikel: \\
Menerima 2 November 2016 \\
Revisi 6 Februari 2018 \\
Diterima 7 Februari 2018 \\
Online 5 April 2020 \\
\hline
\end{tabular}

Kata kunci:

algoritma genetika

jalur independen

kasus uji

test case generation

\section{Keywords:}

genetic algorithm

independenth path

test case

test case generation

Style APA dalam menyitasi
artikel ini:
Setyawan, M. A., Pradana,
F., \& Priyambadha, B.
(2020). Pengembangan
sistem otomatisasi
pembangkitan kasus uji
dengan algoritma genetika
dan method test case
generation. TEKNOLOGI:
Jurnal Ilmiah Sistem
Informasi, 10(1), 1-9.

\begin{abstract}
ABSTRAK
Pengujian perangkat lunak merupakan salah satu bagian penting dari pembuatan perangkat lunak. Pada pengujian perangkat lunak terdapat pengujian unit. Pengujian unit merupakan proses pengujian komponen yang berfokus untuk memverifikasi unit terkecil pada perancangan perangkat lunak. Pada tahap pengujian unit terdapat proses pembangkitan kasus uji. Selama ini, pembangkitan kasus uji dari suatu kode program dilakukan secara manual sehingga membutuhkan waktu yang lama. Hal ini dikarenakan banyaknya kemungkinan jalur pada kode sumber yang akan diuji. Dalam penelitian ini dibangun suatu sistem otomatis untuk membangkitkan kasus uji. Alur kerja sistem dimulai dari analisa kode sumber dengan Spoon Library, selanjutnya dibentuk CFG (Control Flow Graph) dan DDG (Dynamic Directed Graph). Dari DDG tersebut akan dibangkitkan jalur layak yang terdapat pada DDG, dengan menggunakan algoritma genetika diharapkan dapat mengoptimalkan penentuan jalur independen. Dari masing-masing jalur independen akan dibangkitkan kasus ujinya dengan metode test case generation. Pengujian akurasi sistem pada sistem otomatisasi pembangkit kasus uji dengan jumlah populasi 5, 10 dan 15 serta jumlah maksimum generasi 50, 100, 200 dan 250 dihasilkan jumlah populasi paling optimal yaitu 10 dan maksimum generasi optimal yaitu 200 dengan akurasi 93,33\%. Pada jumlah populasi dan maksimum generasi sesudahnya tidak terjadi peningkatan akurasi yang signifikan. Tiap peningkatan jumlah populasi dan maksimum generasi dapat meningkatkan akurasi sistem.
\end{abstract}

\section{ABSTRACT}

Software testing is one of the most important part of making software. On the software testing there are unit testing. Unit Testing is a process for verifying component, focusing on the smallest unit of software design. In the unit testing phase contained test case generation process. During this time, the generation of test cases of a program code is done manually. In this study, constructed an automated system to generate test cases. The workflow system starts from the analysis of the source code with the library spoon and then create CFG (Control Flow Graph) and DDG (Dynamic Directed graph). From the DDG will be raised feasible path using a genetic algorithm. Furthermore, from fea-sible path sought independenth path which is a path based on the level of uniqueness of the path to the other path. From each independenth path raised the test case with a test case generation method. Testing accuracy of the system on the automation system generating test cases with populations of 5,10 and 15 as well as the maximum number of generations 50, 100, 200 and 250 produced the most optimal population number is 15 and the most optimal maximum generation is 200 with accuracy $93.33 \%$. Each increase in the number of population and maximum generation can improve the accuracy of the system. Level 
accuracy with population number over 10 and maximum generation over 200 has no increace accuracy significant.

Teknologi: Jurnal IImiah Sistem Informasi dengan lisensi CC BY NC SA.

\section{Pendahuluan}

Pengujian perangkat lunak merupakan aspek yang sangat diperlukan, karena secara langsung berpengaruh pada kualitas perangkat lunak pada pelaksanaan proses pengujian yang sistematik memerlukan effort dalam menguji software (Chaudhary \& Yadav, 2012). Proses pengujian sendiri terdiri dari beberapa tahap, diantaranya modul pengujian, pengujian integrasi, pengujian sistem, dan pengujian instalasi. Semua aktivitas pengujian dari modul yang berbeda tersebut harus diselesaikan dalam waktu yang terbatas dan aktivitas ini normalnya mengkonsumsi sekitar $40-50 \%$ dari total jumlah sumber daya pengembang (Htoon \& Thein, 2005).

Selain itu terdapat Test Case Point (TCP) analisis yang mana merupakan pendekatan untuk melakukan estimasi akurat pada pengujian fungsional projek. Analisis TCP menghasilkan test effort untuk beberapa aktivitas pengujian yang terpisah. Test effort merupakan faktor kunci dalam melakukan testing, karena hal ini yang menentukan kompleksitas dari keseluruhan siklus testing mulai dari usaha menerjemahkan pembuatan test sampai usaha pengeksekusian test. Analisis TCP tersebut terdiri dari empat modul yang berbeda yaitu: TCP, automated script generation, manual test execution, dan automated test execution (Chaudhary \& Yadav, 2012).

Pada tahap test case generation terjadi pembuatan test case. Estimasi jumlah test case yang dibuat ditentukan oleh estimasi function point (Capers, 1996). Selanjutnya usaha pembuatan test case dalam person-hours dihitung. Dalam hal ini, waktu dalam pembuatan test case dapat dipersingkat jika dilakukan secara otomatis.

Pada proses pembangkitan test case yang konvensional menurut Watson dan McCabe (1996) memiliki empat langkah, yaitu menghitung graph program, menghitung cyclomatic complexity, memilih himpunan basis path, dan membangkitkan test case dari tiap path. Saat membangkitkan himpunan basis path secara otomatis peneliti menggunakan proses algoritma genetika yang diusulkan oleh Ahmed S. Ghiduk (Ghiduk, 2014). Algoritma genetika yang diusulkan terdiri dari proses encoding, initial population, evaluation function, selection, reproduction, dan elitist. Berdasarkan dua algoritma tersebut, peneliti membangun suatu sistem pembangkit test case dengan algoritma genetika dan test case generation pada kode program Java. Konsep dari sistem yang dibangun ialah menerjemahkan suatu kode program Java dari suatu Java file ke dalam jalur independent path.

Selanjutnya, jalur tersebut dianalisa untuk setiap test case yang mendukung masing-masing jalur tersebut. Dengan dibuatnya sistem otomatis pembangkit kasus uji dengan algoritma genetika dan test case generation pada kode diharapkan dapat mempercepat waktu, menghemat tenaga dan biaya dalam tahap test case generation pada software testing.

\section{State of the Art}

\subsection{Basis path testing}

Basis path testing merupakan salah satu kriteria struktural testing yang kuat. Basis path testing membutuhkan jumlah dari test path sama terhadap cyclomatic complexity program, di mana tiap path merupakan independent path dan semua edges dalam Control-Flow Graph (CFG) dicakup seluruh path dalam himpunan basis path (Ghiduk, 2014). Metode yang ditemukan Watson dan McCabe (1996) dalam menangani basis path testing memiliki empat langkah, yaitu 1) Menghitung graph program, 2) Menghitung cyclomatic complexity, memilih himpunan basis path, generating test cases dari tiap path.

Independent path merupakan path dalam program, di mana sekurangnya satu edge dari path tersebut tidak pernah tampak path yang lain dalam CFG basis set of paths and basis path. Sebuah himpunan basis path merupakan himpunan dari path. Setiap path harus memenuhi tiga kondisi berikut: Setiap path harus sebuah independent path, semua edges dalam CFG harus dicakup semua path dalam himpunan basis. Setiap path tidak mengandung himpunan basis path yang dapat dibentuk dari operasi linier di antara path dalam himpunan tersebut.

\subsection{Algoritma genetika untuk otomatisasi generasi dari basis test path}

Genetic Algorithm (GA) yang diusulkan Ghiduk (2014) untuk menghasilkan basis test path dari software

Pengembangan sistem otomatisasi pembangkitan kasus uji dengan algoritma ... $\quad$ http://doi.org/10.26594/teknologi.v10i1.1912 Teknologi: Jurnal IImiah Sistem Informasi dengan lisensi CC BY NC SA. 
yang diuji secara otomatis, di mana menggunakan fungsi fitness baru untuk mengevaluasi basis path yang dihasilkan. Contoh kasus program dengan CFG dan DDG yang diambil terlihat pada Gambar 1.

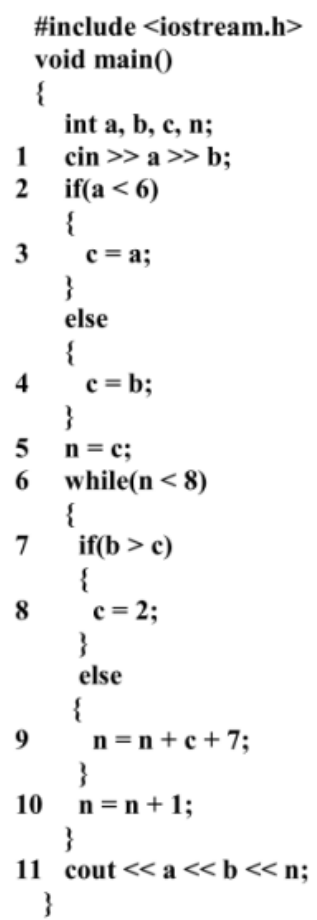

(a)

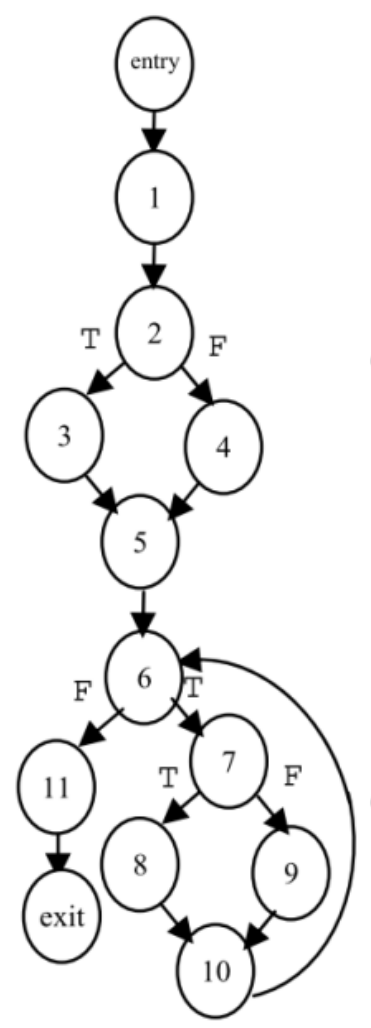

(b)

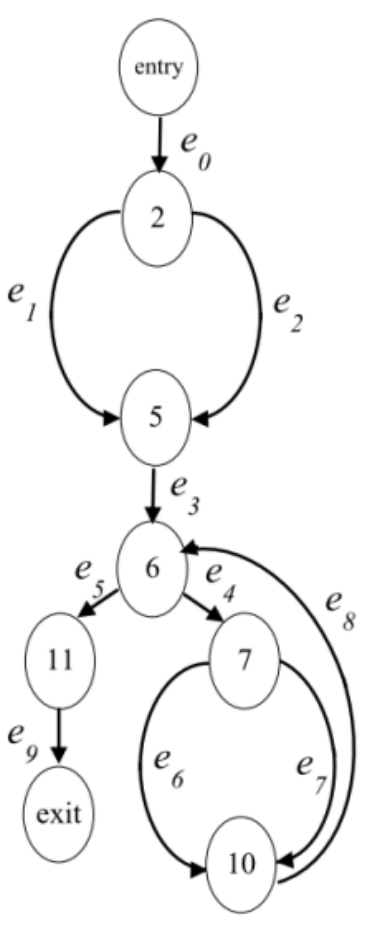

(c)

Gambar 1. Algoritma Genetik

Adapun penjelasan dari Gambar 1 adalah sebagai berikut:

1) Lingkup pencarian algoritma

Lingkup pencarian algoritma dirumuskan seperti pada Persamaan 1 ,

$D=\{\forall e \mid e \in D D G$ dan e dicapai dari entry dan mencapai exit $\}$

(1)

di mana $D$ merupakan lingkup pencarian algoritma genetika dan $e$ dan edge dari $d d$-graph. Sebagai contoh pada Gambar 1 himpunan dari edges $D=\left\{\boldsymbol{e}_{0}, \boldsymbol{e}_{1}, \boldsymbol{e}_{2}, \boldsymbol{e}_{3}, \boldsymbol{e}_{4}, \boldsymbol{e}_{5}, \boldsymbol{e}_{6}, \boldsymbol{e}_{7}, \boldsymbol{e}_{8}, \boldsymbol{e}_{9}\right\}$.

2) Encoding

Encoding merupakan proses merepresentasikan gen individu, dengan Persamaan 2,

M: $i \in d d-g r a p h$

di mana $M$ merupakan mapping dari kromosom dengan $i$ sebagai index kromosom dan $\boldsymbol{e}_{\boldsymbol{i}}$ merupakan index dari edges pada $\boldsymbol{d} \boldsymbol{d}$ - graph. Sebagai contoh pada Gambar 1 contoh kromosom: $(\mathbf{0}, \mathbf{1}, \mathbf{3}, \mathbf{5}, \mathbf{9})$ dengan menggunakan $M$, kromosom dipetakan dalam path $\boldsymbol{p}=\left\{\boldsymbol{e}_{\mathbf{0}}, \boldsymbol{e}_{\mathbf{1}}, \boldsymbol{e}_{\mathbf{3}}, \boldsymbol{e}_{5}, \boldsymbol{e}_{\mathbf{9}}\right\}$.

3) Initial population

Setiap chromosome direpresentasikan sebagai vector integer. Kami secara acak menghasilkan population size (PS) integer vector (chromosome) dengan panjang 2 untuk merepresentasikan populasi awal, di mana PS sebagai panjang ukuran populasi.

4) Evaluation function

Dalam menghitung nilai fitness $\boldsymbol{f t}(\boldsymbol{v i})$ untuk setiap chromosome vi $(\boldsymbol{i}=\mathbf{1}, \ldots, \boldsymbol{P S})$ dihitung sebagai berdasarkan Persamaan 3,

$f t(v i)^{n}=\sum_{j=1}^{d(v i)} w(e j)$

di mana, $d(v i)$ adalah jumlah edges berdekatan dalam kromosom $v i, w(e j)$ adalah berat (probability) dari edge e $j$ dalam kromosom $v i, w(e j)=L(1 v i)$, di mana $L(v i)$ panjang dari kromosom vi. Fungsi fitness dapat ditulis dengan jumlah edges yang berdekatan dibagi dengan total jumlah edges dalam kromosom yang sama.

5) Selection 
Proses seleksi yang digunakan dalam GA yang diusulkan menggunakan roulette wheel. Proses seleksi didasarkan pada pemutaran roulete wheel sebanyak populasi. Setiap kali kita memilih satu single kromosom untuk populasi baru.

6) Reproduction

Proses reproduksi dibagi ke dalam tiga proses yaitu crossover, mutation, dan breeding. Penjelasan dari tiap proses tersebut dijelaskan sebagai berikut:

a. Crossover: GA yang diusulkan menggunakan uniform crossover untuk menukar informasi pada posisi random dua kromosom yang terpilih untuk menghasilkan dua kromosom baru. Setiap pasangan kromosom menghasilkan sebuah bilangan random integer pos dari rentang $[2 \ldots \boldsymbol{L}-$ 1] ( $L$ adalah jumlah edges dalam kromosom).

b. Mutation: Prosedure pada proses mutasi GA yang diusulkan sebagai berikut:

1. Hasilkan sebuah bilangan random $r$ dari rentang $[\mathbf{0} \ldots \mathbf{1}]$;

2. Jika $\boldsymbol{r}<\boldsymbol{M P}$ maka mutasikan cell dengan mengganti edge dengan edges lain yang merupakan siblings (edges dengan parent sama disebut siblings)

c. Breeding: Memungkinkan interaksi terbatas antara sub-populasi melalui prosedur 'pembiakan silang' di mana anggota sub-populasi yang dipilih berbaur untuk membentuk populasi gabungan untuk optimasi lebih lanjut (Pham \& Karaboga, 1998).

7) Elitist

Fungsi elitist meningkatkan populasi sekarang dengan menyimpan satu copy anggota terbaik dari populasi sebelumnya.

8) The stop condition

Terdapat dua kasus kondisi berhenti. Pertama, test path yang dihasilkan telah memenuhi kondisi himpunan basis path. Kedua, jumlah generasi mencapai jumlah maksimum generasi.

\subsection{Test case generation methods}

Algoritma ini Wijayasiriwardhane, Wijayarathna, \& Karunarathna (2011) secara simbolis mengeksekusi tiap eksekusi path yang dilewati program berdasarkan pada elements dari sebuah basis path yang terdapat pada flow graph dan membangkitkan test case yang terdapat pada basis path testing. Algoritma ini mengambil independent path secara linier dari flow graph dan melintasi jalur dari node sumber ke node akhir dengan mengunjungi semua node pada jalur. Ketika node dikunjungi, algoritma ini mengeksekusi statement yang berhubungan dalam program secara simbolis. Algoritma ini memperlakukan input variabel dan parameter pada program sebagai input test case. Hal ini, menghasilkan expected output dan ekspresi dari setiap decision yang dibuat selama mengekseskusi jalur yang berhubungan dengan input test case.

\subsection{Spoon}

Spoon merupakan sebuah library yang dapat digunakan untuk menganalisa dan merubah kode program dengan bahasa Java. Spoon memungkinkan pengembang untuk menulis dengan cakupan besar dalam menganalisa domain yang spesifik dan merubahnya dengan mudah sesuai kebutuhan (Pawlak, Monperrus, Petitprez, Noguera, \& Seinturier, 2016).

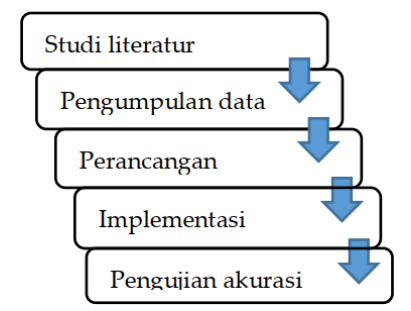

Gambar 2. Metode penelitian

\section{Metode Penelitian}

Metode yang dilakukan dalam penelitian ini dikerjakan dengan beberapa tahapan, antara lain pengumpulan data, perancangan algoritma, implementasi sistem, pengujian akurasi. Gambar 2 menggambarkan urutan metode dalam penelitian ini.

\subsection{Studi literatur}


Studi literatur merupakan metode yang digunakan untuk mencari dasar konsep dan kajian yang dapat digunakan dalam penelitian ini. Literatur tersebut dapat diperoleh dari buku, jurnal, buku, penelitian sebelumnya dan dokumentasi project. Bagian studi literatur ini mencakup teori diantaranya adalah sebagai berikut:
a. Basis path testing
b. Algoritma genetika untuk otomatisasi generasi dari basis path
c. Test case generation
d. Spoon

\subsection{Pengumpulan data}

Pada penelitian ini pengumpulan data didapatkan dari file kode sumber berekstensi Java yang diperoleh dari website freesourcecode.net. Dari file tersebut hanya diambil beberapa metode saja. Metode tersebut diambil sebagian untuk melakukan uji coba kakas bantu pembangkitan jalur independen. Tabel 1 menunjukan metode yang digunakan pada penelitian ini.

Tabel 1. Metode uji coba

\begin{tabular}{lllr}
\hline Nama Kelas & Nama Metode & Kode Program & Jumlah Kasus Uji Coba \\
\hline InsertionSort & Insert & M\#1 & 4 \\
BinaryHeap & getFirst & M\#2 & 2 \\
BinaryHeap & Remove & M\#3 & 2 \\
BinaryHeap & Clear & M\#4 & M\#5 \\
BinaryHeap & rebuildHeap & M\#6 & 5 \\
Prim & Weight & M\#7 & 3 \\
Prim & findNode & M\#8 & 3 \\
Prim & draw_arrow & M\#9 & 2 \\
Prim & remove_pre_s & M\#10 & 3 \\
Prim & step3 & M\#11 & 4 \\
Prim & paintEdge & M\#12 & 11 \\
Prim & paintNode & M\#13 & 8 \\
Prim & init_sub & M\#14 & 4 \\
Prim & mousePres & M\#15 & 4 \\
Kruskal & isPresent & & 4 \\
\hline
\end{tabular}

\subsection{Perancangan}

Perancangan algoritma yang digunakan pada penelitian ini menggunakan GA (Ghiduk, 2014). Parameter-parameter pada algoritma tersebut antara lain, PopSize merupakan ukuran populasi dari GA, maksimum generasi merupakan jumlah maksimal generasi yang dihasilkan, Probability Crossover merupakan peluang dari terjadinya proses crossover pada suatu populasi, Probability Mutation merupakan peluang dari terjadinya proses mutasi pada suatu populasi. Edge merupakan gen dari suatu kromosom yang terdiri dari node awal dan berakhir di node akhir dari suatu lintasan pada DDG.

Panjang kromosom dari suatu individu bervariasi mulai dari 2 hingga maksimum generasi. Hal dikarenakan pada tiap generasi panjang kromosom bertambah satu. GA yang diusulkan Ghiduk (2014) untuk menghasilkan basis test path dari perangkat lunak yang diuji secara otomatis, di mana menggunakan fungsi fitness baru untuk mengevaluasi basis path yang dihasilkan. Proses awal yang dilakukan dalam Algoritma Genetika yaitu dilakukan inisialisasi populasi. Setiap kromosom direpresentasikan sebagai integer vector.

Secara acak menghasilkan PS integer vector (kromosom) dengan panjang 2 untuk merepresentasikan populasi awal, di mana PS sebagai panjang ukuran populasi. Contoh dari inisialisasi populasi dijelaskan pada Tabel 2.

Dari setiap kromosom dilakukan perhitungan nilai fitness $f t(v i)$ untuk setiap kromosom $v i(i=$ $1, \ldots, P S)$ dihitung menggunakan Persamaan 4,

$f t(v i)^{n}=\sum_{j=1}^{d(v i)} w(e j)$

di mana, $d(v i)$ adalah jumlah edges berdekatan dalam kromosom $v i$, w(e j) adalah berat (probability) dari edge e $j$ dalam kromosom $v i, w(e j)=L(1 v i)$, di mana $L(v i)$ panjang dari kromosom vi. Fungsi fitness dapat ditulis dengan jumlah edges yang berdekatan dibagi dengan total jumlah edges dalam kromosom yang 
sama. Proses awal dari algoritma genetika ini dengan melakukan proses crossover. Dalam proses crossover, untuk menentukan pasangan dilakukan proses seleksi menggunakan roulette wheel. Proses seleksi didasarkan pada pemutaran roulette wheel sebanyak populasi. Contoh dari proses ini diperlihatkan pada Tabel 3.

Tabel 2. Inisialisasi populasi (Ghiduk, 2014)

\begin{tabular}{cc}
\hline Kromosom & Fitness \\
\hline$e_{0} e_{9}$ & 0,0 \\
$e_{0} e_{9}$ & 0,0 \\
$e_{0} e_{9}$ & 0,0 \\
$e_{0} e_{9}$ & 0,0 \\
\hline
\end{tabular}

Tabel 3. Contoh proses seleksi

\begin{tabular}{clccc}
\hline C \# & Jalur & RF & CF & r \\
\hline C1 & $e_{0}, e_{1}$, & 0,25 & 0,25 & 0,70 \\
& $e_{3}, e_{5}$, \\
& & & \\
C2 & $e_{9}$ & & & \\
& $e_{0}, e_{2}$, & 0,25 & 0,50 & 0,20 \\
& $e_{3}, e_{4}$, \\
& & & & \\
C3 & $e_{9}$ \\
& $e_{0}, e_{2}$, & 0,25 & 0,75 & 0,80 \\
& $e_{3}, e_{5}$, \\
& $e_{9}$ \\
C4 & & & \\
& $e_{0}, e_{1}$, & 0,25 & 1,00 & 0,15 \\
& $e_{3,}, e_{4}$, \\
& $e_{9}$ & & & \\
\hline
\end{tabular}

Pada Tabel 3 kolom C\# merupakan kromosom kesekian dari suatu populasi. Kolom RF merupakan nilai relative fitness dari masing-masing kromosom yang ada. Nilai ini didapatkan dari 1 dibagi dengan ukuran populasi. Kolom CF merupakan nilai cumulative fitness yang dihitung dengan nilai relative fitness dari suatu kromosom ditambah dengan nilai cumulative fitness sebelumnya. Kolom $r$ merupakan nilai random dari 0 sampai 1 sebagai acuan memilih pasangan dari suatu kromosom. Kolom $P$ merupakan pasangan yang didapatkan.

Tahap selanjutnya yaitu proses reproduksi dibagi ke dalam tiga proses yaitu crossover, mutation, dan breeding. Penjelasan dari tiap proses tersebut dijelaskan sebagai berikut:

a. Crossover: GA yang diusulkan menggunakan uniform crossover untuk menukar informasi pada posisi random dua kromosom yang terpilih untuk menghasilkan dua kromosom baru. Setiap pasangan kromosom menghasilkan sebuah bilangan random integer pos dari rentang $[2 \ldots . L-1]$ ( $L$ adalah jumlah edges dalam kromosom).

Contoh dari proses crossover sebagai berikut:

Individu $e_{0}, e_{2}, e_{3}, e_{4}, e_{9}$ dengan $e_{0}, e_{1}, e_{3}, e_{5}, e_{9}$ dilakukan crossover dengan titik potong posisi 3 menghasilkan offspring $e_{0}, e_{2}, e_{3}, e_{5}, e_{9}$ dan $e_{0}, e_{1}, e_{3}, e_{4}, e_{9}$.

b. Mutation: prosedur pada proses mutasi GA yang diusulkan sebagai berikut. Hasilkan sebuah bilangan random $r$ dari rentang [0...1]; Jika $r<M P$ maka mutasikan cell dengan mengganti edge dengan edges lain yang merupakan siblings ( edges dengan parent sama disebut siblings).

Contoh dari proses mutation diperlihatkan pada Tabel 4. Tabel 4. Contoh proses seleksi

\begin{tabular}{ccc}
\hline Kromosom & $\boldsymbol{R}$ & Kromosom Baru \\
\hline$e_{0}, e_{1}, e_{3}, e_{4}, e_{9}$ & 0,$5 ; 0,1 ; 0,1 ; 0,2 ; 0,1$ & 0,25 \\
\hline
\end{tabular}

Pada Tabel 4, $\mathrm{C} 1$ merupakan kromosom ke-1 dari populasi. $R$ merupakan nilai random masingmasing gen. Pada $\mathrm{C} 1$ diketahui bahwa nilai $R$ terkecil dan paling awal dijumpai dari gen yang terdapat pada $\mathrm{C} 1$ adalah $e_{1}$ dengan nilai $R$ 0,1. Oleh karena itu, $e_{1}$ digantikan dengan sibling yaitu $e_{2}$. Sehingga C1 baru yang dihasilkan adalah $e_{0}, e_{2}, e_{3}, e_{4}, e_{9}$. Proses ini akan diulangi sebanyak $P M \times$ popSize $\times$ lengthCell $=0,15 \times 4 \times 5=10$. Breeding adalah operator breeding berjalan dengan cara berikut:

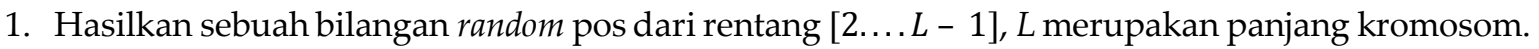
Bilangan pos mengindikasikan titik breeding. 
2. Identifikasikan edge pada posisi pos dan secara random pilih suksesor edges tersebut. Lalu, sisipkan suksesor edges pada posisi pos +1 dan tambahkan panjang kromosom satu.

Contoh dari proses breeding diperlihatkan pada Tabel 5.

Tabel 5. Contoh proses breeding

\begin{tabular}{lll}
\hline \multicolumn{1}{c}{ Populasi Sekarang } & Suksesor & Populasi Baru \\
\hline$e_{0}, e_{2}, e_{3}, \boldsymbol{e}_{5}, e_{9}$ & $e_{9}$ & $e_{0}, e_{2}, e_{3}, e_{4}, e_{9}, e_{9}$ \\
$e_{0}, e_{2}, e_{3}, \boldsymbol{e}_{4}, e_{9}$ & $e_{6}, e_{7}$ & $e_{0}, e_{1}, e_{3}, e_{4}, e_{6}, e_{9}$ \\
$e_{0}, e_{2}, e_{3}, \boldsymbol{e}_{5}, e_{9}$ & $e_{9}$ & $e_{0}, e_{2}, e_{3}, e_{5}, e_{9}, e_{9}$ \\
$e_{0}, e_{1}, e_{3}, \boldsymbol{e}_{5}, e_{9}$ & $e_{9}$ & $e_{0}, e_{1}, e_{3}, e_{5}, e_{9}, e_{9}$ \\
\hline
\end{tabular}

Setelah proses reproduksi selesai, tahap selanjutnya dilakukan proses elitist. Fungsi elitist meningkatkan populasi sekarang dengan menyimpan satu copy anggota terbaik dari populasi sebelumnya. Jika anggota terbaik dari populasi sebelumnya lebih baik dari anggota terbaik dari populasi sekarang, maka anggota terburuk dari populasi sekarang digantikan dengan anggota terbaik dari populasi sebelumnya. Setelah semua proses dalam algoritma genetika dilakukan, akan dilakukan pengecekan kondisi berhenti. Terdapat dua kasus kondisi berhenti. Pertama, test path yang dihasilkan telah memenuhi kondisi himpunan basis path. Kedua, jumlah generasi mencapai jumlah maksimum generasi.

\subsection{Implementasi}

Implementasi sistem merupakan tahapan membangun sistem otomatisasi pembangkitan kasus uji dengan menggunakan bahasa pemrograman Java yang didasarkan pada perancangan yang telah dibuat. Tahapan-tahapan yang ada dalam implementasi antara lain:

1. Membuat antarmuka sistem menggunakan tampilan dengan library java.awt.swing.

2. Implementasi parsing kode sumber menggunakan library Spoon. Implementasi ini digunakan untuk membaca masukan kode sumber dan membentuk CFG dan DDG dari kode sumber tersebut.

3. Implementasi algoritma genetika berdasarkan perancangan algoritma genetika yang dibuat implementasi metode test case generation berdasarkan paper Wijayasiriwardhane, Wijayarathna, dan Karunarathna (2011).

\subsection{Pengujian akurasi}

Pengujian akurasi sistem dilakukan dengan masukan jumlah populasi 5, 10 dan 15 serta jumlah maksimum generasi 50, 100, 200 dan 250. Tahapan pengujian yang dilakukan terdiri dari beberapa tahapan yaitu:

1. Lakukan proses pembangkitan kasus uji dari file kode sumber menggunakan sistem dan secara manual.

2. Lakukan proses pembangkitan pada suatu metode sebanyak 10 kali dengan jumlah populasi dan maksimum generasi tertentu.

3. Hitung jumlah seluruh kasus uji yang benar untuk semua metode.

4. Hitung akurasi berdasarkan jumlah kasus uji yang benar dibagi jumlah keseluruhan proses pembangkitan.

\section{Hasil dan Pembahasan}

Hasil dan pembahasan merupakan tahap pengujian hasil dari perancangan dan implementasi sistem otomatisasi pembangkitan kasus uji. Berikut ini merupakan grafik hasil pengujian akurasi sistem yang telah dilakukan, ditunjukkan pada Gambar 3.

Pada Gambar 3 menunjukkan bahwa peningkatan jumlah populasi dan maksimum generasi dapat meningkatkan akurasi sistem. Pengujian akurasi sistem pada sistem otomatisasi pembangkit kasus uji dengan jumlah populasi 5, 10 dan 15 serta jumlah maksimum generasi 50, 100, 200 dan 250 dihasilkan jumlah populasi paling optimal yaitu 10 dan maksimum generasi optimal yaitu 200 dengan akurasi $93,33 \%$. Pada jumlah populasi dan maksimum generasi sesudahnya tidak terjadi peningkatan akurasi yang signifikan. Tiap peningkatan jumlah populasi dan maksimum generasi dapat meningkatkan akurasi sistem. Peningkatan jumlah populasi yang dapat meningkatkan akurasi sistem dikarenakan semakin banyak populasi maka semakin banyak kombinasi yang dilakukan sehingga lebih banyak ditemukan feasible path. 


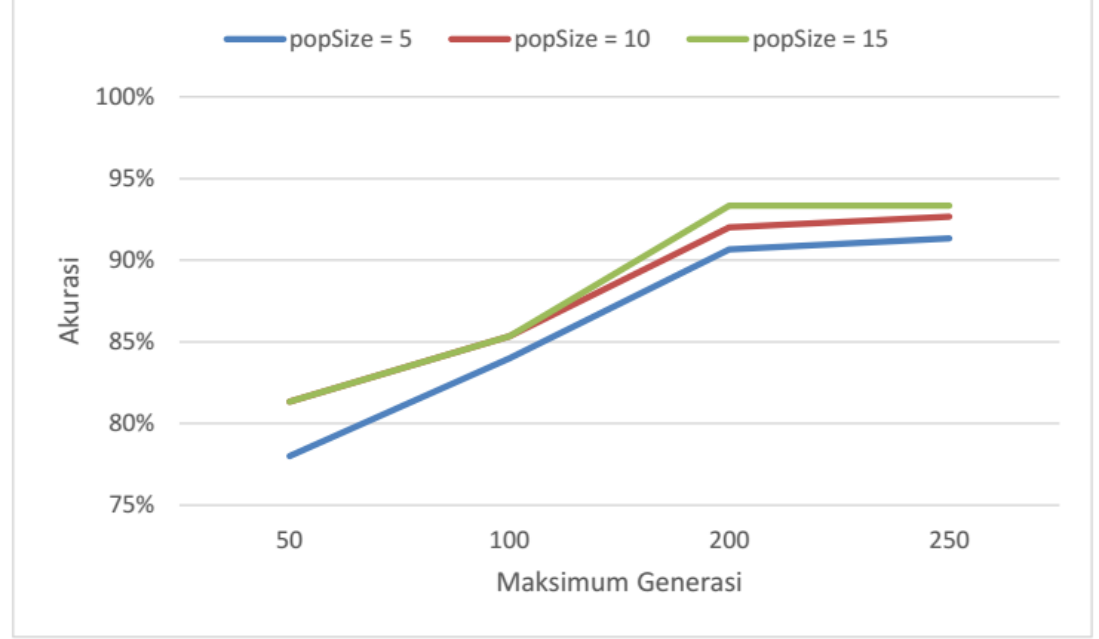

Gambar 3. Grafik uji akurasi

Sedangkan, peningkatan maksimum generasi dapat meningkatkan jumlah kombinasi kromosom dan panjang kromosom. Dari penjelasan mengenai peningkatan jumlah populasi dan maksimum generasi dapat diketahui bahwa, penyebab dari kurangnya akurasi adalah kurangnya kombinasi kromosom yang dilakukan dan kurangnya panjang kromosom untuk suatu path yang memiliki panjang melebihi jumlah maksimum generasi.

Dengan nilai akurasi 93,33\% dapat dikatakan bahwa sistem otomatisasi yang dikembangkan sesuai dengan yang diharapkan. Sistem ini dapat menggantikan proses perhitungan secara manual, sehingga dapat mempersingkat waktu dan biaya dalam proses pengujian perangkat lunak khususnya pada pengujian unit method jika dilakukan dengan manual.

\section{Kesimpulan}

Berdasarkan perancangan, implementasi dan hasil pengujian dari sistem, maka didapat kesimpulan, di antaranya adalah 1) Dalam mendukung proses algoritma genetika dibangun dua kelas yaitu Edge sebagai gen dan Path sebagai kromosom. Sistem otomatisasi pembangkit kasus uji memiliki tiga fitur yaitu memasukkan file kode sumber, membangkitkan kasus uji dan menyimpan hasil pembangkitan kasus uji, 2) Pengujian akurasi sistem pada sistem otomatisasi pembangkit kasus uji dengan jumlah populasi 5, 10 dan 15 serta jumlah maksimum generasi 50, 100, 200 dan 250 dihasilkan jumlah populasi paling optimal yaitu 10 dan maksimum generasi optimal yaitu 200 karena jumlah populasi dan maksimum generasi sesudahnya tidak terjadi peningkatan akurasi yang signifikan. 3) Pengujian akurasi sistem adalah 93,33\%, sehingga bisa dikatakan memiliki tingkat keakuratan tinggi. Sehingga dengan menggunakan sistem ini pengguna dapat mempersingkat waktu dan biaya jika dibandingkan dengan manual. 4) Algoritma Genetika memiliki karakteristik yaitu semakin banyak iterasi hasilnya akan semakin akurat. Namun apabila iterasi yang sama diberlakukan pada semua tingkat kompleksitas kode terlalu berlebihan. Perlu dilakukan penelitian lebih lanjut mengenai iterasi yang optimal pada penerapan algoritma genetika. Sehingga iterasi GA disesuaikan dengan tingkat kompleksitas kode.

\section{Referensi}

Capers, J. (1996). Applied software measurement (Second Edition ed.). McGraw-Hill.

Chaudhary, P., \& Yadav, C. S. (2012). An Approach for Calculating the Effort Needed on Testing Projects. International Journal of Advanced Research in Computer Engineering \& Technology, 1(1), 035-040.

Ghiduk, A. S. (2014). Automatic generation of basis test paths using variable length genetic algorithm. Information Processing Letters, 114(6), 304-316. doi:https://doi.org/10.1016/j.ipl.2014.01.009

Htoon, C., \& Thein, N. L. (2005). Model-based Testing Considering Cost, Reliability and Software Quality. 6th Asia-Pacific Symposium on Information and Telecommunication Technologies. Yangon, Myanmar: IEEE. doi:https://doi.org/10.1109/APSITT.2005.203649

Pawlak, R., Monperrus, M., Petitprez, N., Noguera, C., \& Seinturier, L. (2016). SPOON: A library for implementing analyses and transformations of Java source code. Software: Practise and Experience, 46(9), 1155-1179. doi:https://doi.org/10.1002/spe.2346 
Pham, D. T., \& Karaboga, D. (1998). Cross breeding in genetic optimisation and its application to fuzzy logic controller design. Artificial Intelligence in Engineering, 12(1-2), 15-20. doi:https://doi.org/10.1016/S0954-1810(96)00034-9

Watson, A. H., \& McCabe, T. J. (1996). Structured Testing: A Testing Methodology Using the Cyclomatic Complexity Metric. Gaithersburg, Maryland: National Institute of Standards and Technology (NIST).

Wijayasiriwardhane, T. K., Wijayarathna, P. G., \& Karunarathna, D. D. (2011). An automated tool to generate test cases for performing basis path testing. International Conference on Advances in ICT for Emerging Regions (ICTer). Colombo, Sri Lanka: IEEE. doi:https://doi.org/10.1109/ICTer.2011.6075032 